Przegląd Prawa Konstytucyjnego

- -ISSN 2082-1212--------

DOI 10.15804/ppk.2017.02.13

$-\mathrm{Nr} 2(36) / 2017$

\title{
Recenzja
}

\section{Prawo międzynarodowe i europejskie a sądownictwo konstytucyjne, red. Piotr Tuleja, ISBN 978-83-64506-18-5, Wydawnictwo JAK, Kraków 2015, ss. 136}

Znaczenie norm prawa międzynarodowego i europejskiego dla prawa krajowego jest zagadnieniem ogromnej wagi w polskim dyskursie prawniczym. Prezentowana publikacja stanowi zarówno wartościowy przegląd rozwiązań przyjętych w najbardziej reprezentatywnych porządkach prawnych ale także analizę linii orzeczniczej polskiego Trybunału Konstytucyjnego skonfrontowanej z dorobkiem trybunałów strasburskiego i luksemburskiego.

Pierwszy z artykułów, autorstwa P. Czarnego pt.: „Federalny Trybunał Konstytucyjny w Niemczech a prawo międzynarodowe" stanowi wnikliwą analizę orzecznictwa najbardziej wpływowego sądu konstytucyjnego w Europie $\mathrm{w}$ kontekście umiejscowienia norm prawa międzynarodowego $\mathrm{w}$ federalnym porządku prawnym. Autor przywołuje wiele ciekawych zagadnień, z czego na szczególną uwagę zasługuje opis relacji istniejących w niemieckiej jurysprudencji koncepcji dotyczących inkorporacji elementów prawa międzynarodowego do niemieckiego prawa federalnego - teorii transformacji oraz teorii wykonania. Przedstawia również kolejne etapy wykładni dokonywanej przez FTK w celu uznania normy prawa międzynarodowego za element prawa federalnego. Pierwszym z nich jest ustalenie istnienia danej normy, następnie zaś konieczne jest przeanalizowanie poziomu jej akceptacji w obcych porządkach prawnych. W toku orzekania Trybunał jest 
zobligowany także do ustalenia dokładnej jej treści by w końcu mógł ocenić, czy posiada ona charakter samowykonalny oraz czy normę tę, która jest pierwotnie adresowana do państw można przekształcić poprzez zastosowanie „teorii zmiany adresatów” w podstawę praw i obowiązków jednostek. W dalszej części wywodu znajduje się analiza znaczenia Konwencji o ochronie praw człowieka i podstawowych wolności (dalej: Konwencja Europejska lub EKPC) oraz jej wykładni dokonywanej przez Europejski Trybunał Praw Człowieka (dalej: ETPC) w orzecznictwie Trybunału w Karlsruhe. Kolejnym z poruszonych $\mathrm{w}$ tekście zagadnień jest pojęcie źródeł prawa międzynarodowego, którymi związane są władze publiczne RFN. Autor uznaje za przekonujący dominujący w niemieckim piśmiennictwie pogląd utożsamiając ich katalog z treścią art. 38 statutu Międzynarodowego Trybunału Sprawiedliwości. Na zakończenie autor przedstawia argumenty przemawiające za uznaniem tezy, że powszechnie uznane normy prawa międzynarodowego również stanowią element prawa federalnego, któremu powinno się przyznać pierwszeństwo przed ustawodawstwem federalnym. Podsumowując analizę tego tekstu stwierdzić należy, że zawiera on odesłania do imponującej literatury źródłowej. Dowodzi to jak głęboko autor wniknął w przedstawione zagadnienie.

Autorem drugiego tekstu, pt.: „ «Prawo międzynarodowe jest częścią naszego prawa» - zmienne koleje norm międzynarodowych w prawie konstytucyjnym Stanów Zjednoczonych Ameryki. Zarys problematyki" jest S. Kubas. Przywołuje bogaty wybór orzecznictwa sądów amerykańskich, głównie Sądu Najwyższego, oraz poglądów doktryny koncentrujących się na ewolucji znaczenia prawa międzynarodowego oraz prawa obcego w amerykańskim porządku prawnym. Autor zauważa, że dla akceptacji prawa międzynarodowego, jego mocy wiążącej a tym samym na wpływu prawa międzynarodowego na prawo federalne decydujące znaczenie miała pozycja Stanów Zjednoczonych na globalnej arenie politycznej. Z przeprowadzonej analizy jasno wynika, że po II wojnie światowej, kiedy USA stały się jednym z dwóch supermocarstw nastawienie piśmiennictwa a przede wszystkim sądów do prawa międzynarodowego stało się zdecydowanie negatywne. Autor wskazuje, że wpływowe kręgi prawnicze uznawały jego źródła za instrument wpływania organizacji międzynarodowych na sytuację wewnętrzną w Stanach Zjednoczonych. Paul B. Stephan, którego poglądy przywołuje autor, przyczyny 
tego stanu rzeczy odnajduje w zerwaniu ciągłości historycznej, wzroście roli państwa administracyjnego, świadomości praktycznego znaczenia orzecznictwa Sądu Najwyższego oraz zaangażowaniu Sądu w sferę praw człowieka. To właśnie w tej sferze, w II połowie XX w. prawo międzynarodowe oraz doświadczenia innych porządków prawnych rzutowały na prawo amerykańskie, zwłaszcza w odniesieniu do dyskryminacji rasowej. Autor wskazuje ponadto, że w opisywanym okresie (tj. od połowy XX w.) sądy w sprawach związanymi z stosunkami międzynarodowymi i sferą polityki zagranicznej pozostają całkowicie związane praktyką egzekutywy w tym względzie. Zdaniem Harolda H. Kocha, utraciły one w ogóle zdolność autorytatywnego wypowiadania się w tych sprawach $\mathrm{z}$ uwagi na polityczny charakter tej materii. Autor zwraca również uwagę na najczęstszą formę wykorzystywania prawa międzynarodowego i obcego w orzecznictwie amerykańskich sądów. Stanowi ono głownie wzmocnienie argumentacji, wywodów składu orzekającego. W tekście znajduje się również analiza najnowszego orzecznictwa Sądu Najwyższego wykorzystującego prawo międzynarodowe, która prowadzi do wniosku, że posługiwanie się nim ma charakter instrumentalny, co $\mathrm{w}$ zasadzie nie stanowi przecież zmiany na przestrzeni ponad dwustuletniej działalności Sądu. Autor przywołuje orzeczenie w sprawie Aktepe v. United States, w którym Sąd odmówił zadośćuczynienia roszczeniom rodzinom tureckich marynarzy statku ostrzelanego z USS Sarratoga uzasadniając to wojskowym charakterem podjętej decyzji, która z tego względu nie powinna podlegać ocenie władzy sądowniczej. Ustalenia dokonane $\mathrm{w}$ tym fragmencie wywodu autora są niezwykle aktualne. W tym miejscu warto zwrócić uwagę na orzeczenie Sądu Najwyższego z kwietnia 2016 r., tj. gdy publikacja była już wydana. Sąd zdecydował w nim o przekazaniu rodzinom amerykańskich żołnierzy, którzy zginęli w ataku wojsk irańskich na bazę w Bejrucie środków finansowych irańskich banków zamrożonych w ramach sankcji nałożonych w konsekwencji tego bombardowania. Przykład ten wzmacnia niezwykle wnikliwy wywód autora o instrumentalnym wykorzystywaniu prawa obcego w orzecznictwie Sądu.

Trzeci z tekstów, którego autorem jest studentka WPiA UJ, Katarzyna Kos dotyczy roli Trybunału Konstytucyjnego w multicentrycznym systemie ochrony praw i wolności jednostki. Najbardziej interesującym problemem poruszanym w tym artykule jest dialog pomiędzy polskimi sądami 
(nie tylko Trybunałem Konstytucyjnym) a ETPC i TSUE. Autorka wskazuje, że poza możliwością kierowania pytań prawnych do tych międzynarodowych organów najistotniejszym instrumentem owej relacji jest wykorzystywanie ich orzecznictwa w procesie wyrokowania. Niezwykle ciekawe mogłyby się okazać ustalenie czy odwołanie do dorobku ETPC i TSUE jest konieczne czy nie ma wyłącznie ornamentacyjnego charakteru w procesie interpretacji postanowień konstytucyjnych?

Kolejny artykuł, pt.: „Skarga konstytucyjna jako środek ochrony konwencyjnych praw i wolności jednostki” autorstwa M. Florczak-Wątor jest kolejnym głosem w dyskusji o praktycznym znaczeniu skargi w polskim porządku prawnym. Autorka w pierwszej kolejności skupia się na konwencyjnych wzorcach kontroli w postępowaniu inicjowanym skargą jednostki. Dochodzi do wniosku, że art. 79 ust. 1 nie może stanowić bezpośredniej podstawy stosowania przepisów EKPCz jako wzorców kontroli konstytucyjności. Z uwagi jednak na oparcie polskiej ustawy zasadniczej w sferze praw i wolności jednostki na postanowieniach Konwencji skarga konstytucja służy także ochronie uprawnień wynikających z Konwencji. Autorka podbudowuje to wskazaniem podobieństw pomiędzy wykładnią art. 45 Konstytucji dokonywaną przez Trybunał Konstytucyjny oraz orzecznictwem trybunału strasburskiego na tle art. 6 EKPC. Drugim z zagadnień poruszonych w analizowanym artykule jest zadośćuczynienie przez polską procedurę rozpoznania skargi konstytucyjnej wymogom, które są stawiane skutecznym środkom ochrony konwencyjnych praw i wolności w art. 13 Konwencji. Autorka zwraca uwagę na dwie podstawowe kwestie- po pierwsze, że EKPC nie narzuca sygnatariuszom sposobu uregulowania tego nadzwyczajnego instrumentu ochrony praw i wolności, stanowi jedynie o zobowiązaniu państw do stworzenia skutecznej procedury odwoławczej. Po drugie wskazuje na nieścisłość w polskim tłumaczeniu tego przepisu, który dotyczy „odwołania od” podczas gdy w tekście angielskojęzycznym mowa jest o „odwołaniu do", co ma bardzo istotne znaczenie. Należy uznać, zdaniem autorki, że przesłanki wynikające $\mathrm{z}$ art. 13 spełniać będzie jedynie środek uruchamiający nowe postępowanie, uruchamiane dopiero po prawomocnym zakończeniu procedury ordynaryjnej. Autorka nie ma wątpliwości, że skarga konstytucyjna jest środkiem odwoławczym w rozumieniu art. 13 Konwencji, ponieważ mimo możliwości zaskarżenia jedynie aktu stanowienia pra- 
wa otwiera drogę do wzruszenia ostatecznego orzeczenia wydanego w sprawie skarżącego zwłaszcza w związku z treścią art. 190 ust. 4 Konstytucji. Trzecim z zagadnień poruszonych przez dr hab. Florczak-Wątor jest kwestia statuowanego art. 35 Konwencji wymogu wyczerpania istniejącej drogi prawnej jako dopuszczalności skierowania skargi indywidualnej do ETPC w odniesieniu do skargi konstytucyjnej. Przesądzenie tej kwestii in abstracto nie jest możliwe, choć w większości wypadków wniesienie skargi konstytucyjnej jest konieczne. Autorka przywołuje jednak sytuację, w której Trybunał Konstytucyjny przyjął linię orzeczniczą odmawiającą rozpoznania skarg konstytucyjnych dotyczących praw naruszonych postanowieniami sądu wydanymi w postępowaniach pomocniczych. Wówczas, zdaniem trybunału starsburskiego, wymóg ten nie powinien wpływać negatywnie na gwarancje praw i wolności jednostki skoro ich ochrona w prawie krajowym jest nieefektywna. Wynika $\mathrm{z}$ tego konieczność dokonania oceny szczególnych uwarunkowań procedury krajowej i jej efektywności indywidualnie, w każdej rozpoznawanej sprawie. Ostatnim z problemów poruszonych przez autorkę jest objęcie postępowania inicjowanego skargą konstytucyjną wymogiem rzetelnego procesu wynikającego z art. 6 Konwencji. W pierwszym rzędzie autorka odnosi się do wymogu rozpatrzenia sprawy w rozsądnym terminie. Zdaniem autorki nie budzi wątpliwości, że kryterium to powinno być brane pod uwagę w stosunku do tego postępowania i to liczonego łącznie z postępowaniem wznowionym po korzystanym dlań wyroku sądu konstytucyjnego aż do wydania ostatecznego orzeczenia w tym postępowaniu. W stosunku do postępowania w ramach kontroli konkretnej w sądach konstytucyjnych, zdaniem autorki, powinno się stosować także zasadę równości broni wynikającej zwłaszcza z jawnego charakteru rozprawy. Stwierdzenie to jest niezmiernie ciekawe zwłaszcza w kontekście obecnego brzmienia ustawy o Trybunale Konstytucyjnym.

Piąty z tekstów, którego autorem jest W. Langer dotyczy kodeksu dobrej praktyki w sprawach wyborczych w orzecznictwie Trybunału Konstytucyjnego. Autor analizuje znaczenie tego źródła soft-law, przyjętego przez Komisję Wenecką, w wyrokach polskiego sądu konstytucyjnego w sprawach związanych z prawem wyborczym. W pierwszej części skupia się na syntezie postanowień Kodeksu dotyczących fundamentalnych zasad prawa wyborczego, tj. powszechności, równości, wolności i bezpośredniości oraz związ- 
ku pluralistycznych wyborów z poszanowaniem praw człowieka. W drugiej części zaś autor przeprowadza analizę wybranych orzeczeń TK, w których Kodeks dobrych praktyk w sprawach wyborczych stanowił zasadniczy fundament argumentów składu orzekającego mimo niewiążącego charakteru. Opracowanie to dobitnie wskazuje na pomocniczy charakter Kodeksu oraz przyjętych przez Komisję Wenecką wytycznych dla trybunalskiej wykładni przepisów prawa wyborczego.

Kolejny z tekstów, autorstwa B. Przywory dotyczy wybranych zagadnień dotyczących Europejskiej Karty Samorządu Lokalnego jako wzorca kontroli prawa w świetle orzecznictwa Trybunału Konstytucyjnego. Interesującą kwestią, która rozpoczyna właściwy wywód jest przypomnienie czytelnikowi, że Karta nie została ratyfikowana za zgodą wyrażoną w ustawie mimo obowiązku uzyskania akceptacji legislatywy. Autor zwraca uwagę na fakt, że nie pozostało to bez wpływu na jej pozycję wobec ustawodawstwa krajowego. Trybunał zgodnie z przyjętą linią orzeczniczą w przypadku, gdy postanowienia umowy międzynarodowej są tożsame $\mathrm{z}$ regulacją konstytucyjną, która stanowi wzorzec kontroli, nie przeprowadza analizy przepisów wynikających z EKSL. W pozostałych wypadkach, postanowienia Karty stanowią akcesoryjną podstawę stwierdzenia zgodności lub niezgodności z ustawą zasadniczą. Autor wskazuje również argumenty przemawiające za możliwością dekodowania z Europejskiej Karty Samorządu Lokalnego minimalnego standardu konstytucyjnego.

Opracowaniem zamykającym tę publikację jest artykuł P. Sarneckiego, pt.: „Zamiast zakończenia: funkcja europejska parlamentu jako przykład internacjonalizacji prawa konsty tucyjnego". Autor przedstawia nie tylko ewolucję sejmowych i senackich komisji, do których właściwości należy opiniowanie inicjatyw organów Unii Europejskiej ale również wyjątkowo żmudny proces negocjacji akcesyjnych oraz dostosowywania prawa polskiego do wymagań stawianych państwom członkowskim UE. Analizowany tekst przekonuje o tym, jak ważką rolę odegrały obie izby polskiego parlamentu w długo oczekiwanej integracji ze zjednoczoną Europą. Docenić należy zwłaszcza pietyzm, z którym autor przywołuje proces kształtowania się praktyki polskiego parlamentu w sferze, którą należałoby nazwać wykonywaniem powierzonej im funkcji europejskiej. Ustalenia dokonane w toku Jego wywodu stanowią cenne kompendium, które z pewnością okaże się pomocne dla 
osób zainteresowanych tą tematyką. Na szczególne podkreślenie zasługuje fakt, że autor dokonuje niezwykle wnikliwej analizy zgromadzonych materiałów źródłowych, zwłaszcza materiałów legislacyjnych oraz uchwał Sejmu publikowanych w Monitorze Polskim. Stanowi to dodatkowy atut Jego wywodu.

Analizowana publikacja jest interesującym głosem w debacie dotyczącej znaczenia źródeł prawa międzynarodowego w polskim systemie prawnym oraz ich wpływie na prawa, wolności i obowiązki jednostek. Autorzy przywołując poglądy doktryny, orzecznictwo Trybunału Konstytucyjnego, Europejskiego Trybunału Praw Człowieka, Sądu Najwyższego Stanów Zjednoczonych oraz Federalnego Trybunału Konstytucyjnego w Karlsruhe dochodzą do niewątpliwie ciekawych wniosków, przez co książka „Prawo międzynarodowe i europejskie a sądownictwo konstytucyjne” stała się jedną z istotnych prac poruszających niezwykle istotny problem relacji pomiędzy elementami multicentrycznego systemu źródeł prawa.

Paweł Króliczek Uniwersytet Śląski w Katowicach 